\title{
PERUBAHAN UPAYA DAN HASIL TANGKAPAN IKAN PELAGIS KECIL DI SEKITAR LAUT JAWA: KAJIAN PASKA KOLAPS PERIKANAN PUKAT CINCIN BESAR
}

\author{
Suwarso'), Wudianto'), dan Suherman Banon Atmaja1) \\ 1) Peneliti pada Balai Riset Perikanan Laut, Muara Baru-Jakarta \\ 2) Peneliti pada Pusat Riset Perikanan Tangkap, Ancol-Jakarta \\ Teregristrasi I tanggal: 16 Juli 2007; Diterima setelah perbaikan tanggal: 31 Maret 2008; \\ Disetujui terbit tanggal: 4 April 2008
}

\begin{abstract}
ABSTRAK
Penyusutan stok (biomassa) ikan pelagis di Laut Jawa dan Selat Makassar akibat peningkatan kapasitas penangkapan yang tak terkontrol diduga menjadi sumber penyebab penurunan produktivitas pukat cincin yang berlangsung secara simultan sejak tahun 1995 sampai dengan sekarang (tahun 2006), serta memberikan hasil tangkapan semakin rendah dan tidak menguntungkan. Kajian tentang perubahan upaya dan hasil tangkapan ikan pelagis pasca collaps perikanan pukat cincin ini didasarkan pada data hasil tangkapan (per spesies) dan upaya (jumlah trip, hari laut) kapal pukat cincin yang mendarat di Pekalongan dan Juwana kurun waktu tahun 1999 sampai dengan 2006. Hasil menunjukkan jumlah kapal aktif berkurang, karena sejumlah kapal tidak lagi dapat beroperasi (bangkrut), sedang kapal yang beroperasi nampak tidak efisien yang terlihat dari jumlah hari laut yang semakin lama, jumlah trip per kapal juga makin menurun. Tidak ada lagi perluasan daerah penangkapan baru karena perluasan telah mencapai maksimum pada tahun 1996. Selain itu, dalam usaha merespon ketidakseimbangan antara hasil yang diperoleh dengan tinggi biaya eksploitasi, beberapa kelompok usaha perikanan bermodal kuat juga melakukan ekspansi (relokasi) daerah penangkapan baru di luar perairan Laut Jawa dan Selat Makassar; transhipment di laut dimungkinkan banyak dilakukan. Penurunan laju tangkap terjadi di hampir seluruh daerah penangkapan, disertai dengan pergeseran komposisi spesies terutama di Jawa bagian timur (Matasirih) dan Selat Makassar. Terutama pada puncak musim hasil tangkapan (musim peralihan antara bulan September sampai dengan Nopember), kategori layang (Decapterus spp.) yang dalam keadaan normal dominan keberadaan tergeser oleh muncul spesies baru, yaitu ikan ayam-ayaman (Aluterus monoceros, Monacanthidae). Selar bentong (Selar crumenophthalmus) cenderung semakin banyak, tetapi banyar (Rastrelliger kanagurta) makin sedikit. Kontrol upaya sangat penting dilakukan kalau tujuan sustainable fisheries akan dicapai; bagi perikanan pelagis Laut Jawa kontrol tersebut dalam hal jumlah dan ukuran kapal, teknologi penangkapan, dan lama di laut.
\end{abstract}

KATAKUNCl: perikanan pukat cincin, ikan pelagis kecil, upaya penangkapan, hasil tangkapan, Laut Jawa

\section{PENDAHULUAN}

Sejak diperkenalkan pertama kali pada tahun 1970 di Batang, Jawa Tengah (Djadjuri, 1978), perikanan pukat cincin makin populer dan berkembang ke berbagai daerah seperti Muncar (tahun 1971 sampai dengan 1973), utara Jawa Timur dan Madura, Pontianak (tahun 1986 atau 1987) dan Pemangkat (tahun 1990). Potier (1998) mengatakan, dalam waktu relatif singkat perikanan ini berkembang menjadi perikanan semi industri dan telah berhasil meningkatkan produksi ikan dengan sangat nyata dari tahun ke tahun; puncak produksi ikan pelagis tercapai pada tahun 1994, yaitu sekitar 100.000 ton di Pekalongan dan 62.000 ton di Juana. Namun, sejak saat itu pendaratan (landing) ikan pelagis oleh pukat cincin tidak pernah lagi menunjukkan kenaikan (Gambar 1); pada tahun 2002 produktivitas pukat cincin kira-kira hanya separuh dari kapasitas volume palka (Atmaja, 2006), dan pada tahun 2005 total landing hanya mencapai 39.000 ton di Pekalongan dan 20.000 ton di Juana, bahkan pada tahun 2006 hanya 22.000 ton di Pekalongan. Dalam Statistik Perikanan Tangkap Indonesia (2003), jumlah armada pukat cincin tercatat 15.685 kapal yang tersebar di seluruh perairan Indonesia, paling banyak di utara Jawa $(30 \%)$ di mana sebagian besar $(51 \%)$ terdapat di Jawa Tengah. Dalam ukuran lebih kecil, pukat cincin mini juga tersebar luas di sepanjang pantai utara Jawa, Labuhan dan Selat Sunda (1986), Lampung dan utara Madura.

Penurunan produktivitas pukat cincin secara simultan pasca puncak produksi (1994) tersebut ternyata merupakan signal yang cukup jelas dari gejala penyusutan stok ikan pelagis di perairan ini seperti dipostulatkan oleh Atmaja (2006); pemulihan stok tidak berlangsung secara cepat akibat nilai 


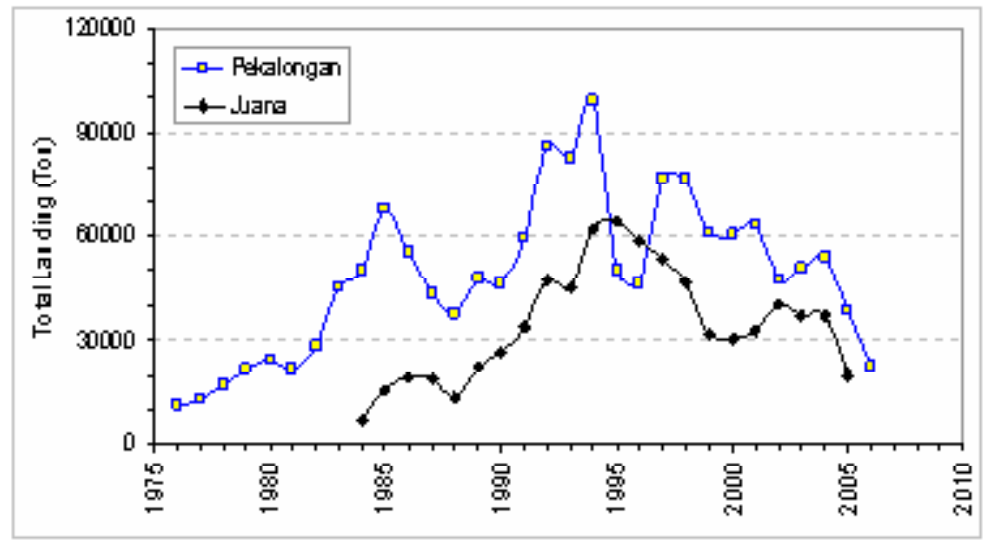

Gambar 1. Perkembangan total landing pukat cincin yang mendarat di Pekalongan dan Juana.

maximum sustainable yield telah melampaui titik optimal sehingga hasil tangkapan tidak menguntungkan secara ekologi maupun ekonomi. Oleh beberapa peneliti ditunjukkan, tidak terlihat kenaikan produksi lebih dari 2 kali lipat (tetapi laju eksploitasi ikan pelagis kecil hanya 1,5 , yaitu dengan produksi 507.530 ton), meskipun Nurhakim et al. (1995) mengatakan kenaikan tingkat maximum sustainable yield 2,3 sampai dengan 2,8 kali lipat. Laporan-laporan tersebut juga tidak menjelaskan tentang perubahan-perubahan yang terjadi pada perikanan seperti perubahan kapasitas penangkapan yang meliputi ukuran kapal, kekuatan mesin, ekspansi daerah penangkapan, dan peningkatan efisiensi penangkapan melalui penggunaan cahaya (lampu sorot) sebagai alat bantu pengumpul ikan menggantikan rumpon. Di lain pihak, data landing pukat cincin Pekalongan dan Juana periode tahun 1991 sampai dengan 1998 menunjukkan bahwa meski maximum sustainable yield meningkat hampir 4 kali lipat dibandingkan periode sebelumnya (tahun 1976 sampai dengan 1981), namun setelah periode tersebut (tahun 1999 sampai dengan 2004) menurun sekitar $30 \%$. Berdasarkan pada parameter fungsi produksi surplus, pada periode tahun 1991 sampai dengan 2004 (periode di mana taktik penangkapan perikanan pukat cincin menggunakan lampu sorot), saat tercapai tingkat maximum sustainable yield sisa biomassa diperkirakan tinggal separuh dari biomassa awal, dan tingkat maximum sustainable yield telah mencapai pada tahun 1993 sampai dengan 1994; pada tahun 2004 sisa biomassa hanya tinggal 23\%. Sedangkan berdasarkan pada data statistik perikanan, yield $\mathrm{Y}_{\text {MSY }}$ tercapai pada tahun 1998 sampai dengan 1999, dan pada tahun 2004 sisa biomassa kira-kira tinggal $28 \%$. Melalui analisis cohort dan produksi ikan siro (Amblygaster sirm) yang didaratkan di Pekalongan dan Juana, Atmaja et al. (2006) juga menunjukkan biomassa ikan siro cenderung terus menurun. Sebelumnya, Durand \& Widodo (1997) menyimpulkan bahwa tingkat eksploitasi perikanan pukat cincin telah mencapai ambang krisis dan lebih bersifat sosial ekonomi daripada bersifat biofisik, perluasan daerah penangkapan telah mencapai maksimum (hampir seluruh daerah penangkapan di Laut Jawa dan Laut Cina Selatan telah dieksploitasi), pendapatan per kapal menurun (kenaikan biaya perbekalan tidak seimbang dengan nilai jual ikan), serta stagnasi hasil tangkapan pada periode tahun 1992 sampai dengan 1995 (seluruh daerah penangkapan telah dieksploitasi dan hasil tangkapan telah mencapai maximum sustainable yield).

Paper ini membahas tentang perubahan-perubahan pada upaya dan hasil tangkapan ikan pelagis oleh pukat cincin yang mendarat di Pekalongan dan Juana pada periode tahun 2002 sampai dengan 2006, yaitu beberapa tahun setelah maximum sustainable yield dan puncak produksi tercapai sebagai risiko perkembangan perikanan dan peningkatan kapasitas penangkapan. Hasil diharapkan dapat berguna sebagai bahan pertimbangan bagi pengelolaan perikanan yang bertanggungjawab dalam arti pengelolaan tersebut akan dapat menjamin penangkapan yang menguntungkan tetapi ketersediaan sumber daya di perairan tetap terjamin dalam jangka panjang (Martosubroto, 2005).

\section{BAHAN DAN METODE}

Data yang digunakan dalam kajian ini berupa data hasil tangkapan dan upaya kapal pukat cincin yang mendarat di Pekalongan dan Juana sebagai tempat pendaratan utama. Pengumpulan data hasil tangkapan per kapal menurut spesies (kategori spesies) dilakukan terhadap seluruh kapal yang 
mendarat di Pelabuhan Perikanan Nusantara Pekalongan (Jawa Tengah) periode tahun 2002 sampai dengan 2006; informasi daerah penangkapan dan jumlah hari di laut diperoleh melalui kantor Syahbandar pelabuhan. Data total hasil tangkapan per kapal periode tahun 1999 sampai dengan 2006 juga dikumpulkan di tempat pendaratan ikan Bajomulyo, Juana, dan tempat pendaratan ikan Tegal (Jawa Tengah) terhadap seluruh kapal yang mendarat. Penentuan daerah asal kapal didasarkan pada registrasi kapal-kapal (SIUP dan SIP) Pekalongan tahun 2004 oleh Pelabuhan Perikanan Nusantara Pekalongan. Kompilasi data dilaksanakan menurut waktu (bulan) dan daerah penangkapan. Kecenderungan pola secara musiman dan lokasi ditunjukkan secara grafikal, dilengkapi dengan nilainilai statistik sederhana.

\section{HASIL DAN BAHASAN}

\section{Perkembangan dan Ekspansi Daerah Penangkapan}

Dengan peningkatan kapasitas penangkapan (ukuran kapal, kekuatan mesin disertai teknologi penangkapan yang lebih modern berupa penggunaan fish sounder, lampu sorot, GPS, dan radio komunikasi) sehingga memungkinkan ruang gerak yang lebih luas, perikanan pukat cincin semi industri (Pekalongan, Juana, dan Tegal) dapat lebih leluasa melakukan penangkapan ke berbagai wilayah perairan, yaitu ke timur sampai dengan Kepulauan Kangean, dan Selat Makassar), ke barat sampai dengan Laut Cina Selatan (Pulau Natuna, Pulau Midai, dan Pulau Pejantan). Komposisi aktivitas penangkapan menurut daerah penangkapan terlihat pada Gambar 2.

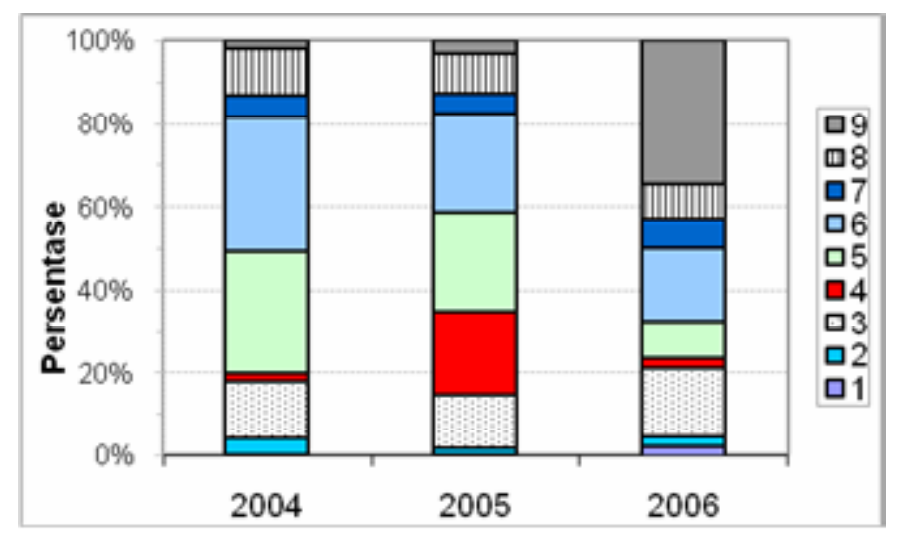

Gambar 2. Komposisi aktivitas penangkapan pukat cincin yang mendarat di Pekalongan menurut daerah penangkapan tahun 2004 sampai dengan 2006 (Daerah penangkapan Tabel 1).

Pada dasarnya tidak ada daerah penangkapan baru karena perluasan daerah penangkapan telah mencapai maksimum sejak tahun 1996 (Durand \& Widodo, 1997). Sedikit pergeseran terlihat pada tahun 2005 sampai dengan 2006; peningkatan aktivitas penangkapan di sekitar Masalembo pada tahun 2005 dan sekitar Bawean pada tahun 2006, hal ini mungkin berkaitan dengan usaha penangkapan ikan gendut atau leather-jackets (Aluterus monoceros, famili Monacanthidae). Aktivitas musiman secara umum tetap, namun dengan kuantitas (jumlah trip) makin menurun. Pada puncak musim timur banyak kapal beroperasi di perairan Natuna (Laut Cina Selatan) dan Selat Karimata, di mana saat itu di Laut Jawa sedang musim paceklik (antara bulan Maret sampai dengan Agustus). Pada musim barat (antara bulan Desember sampai dengan Pebruari) ketika keadaan cuaca dan laut di Laut Jawa tidak menguntungkan untuk penangkapan, sebagian besar aktivitas penangkapan terkonsentrasi di Selat Makassar (Pulau Lumu-lumu dan Pulau Lari-Larian). Usaha penangkapan di utara Tegal, Pekalongan (wilayah 1) dan sekitar Karimunjawa (wilayah 2) tidak menjadi tujuan penangkapan lagi. Terlihat penurunan trip di hampir semua daerah penangkapan utama (Tabel 1). Penurunan jumlah trip menunjukkan gejala-gejala lain yang nampak semakin jelas pada tahun 2006 (kelompok lain-lain pada Gambar 2, Tabel 1), antara lain gejala ekspansi daerah penangkapan ke luar dari perairan Laut Jawa-Selat Makassar-Laut Cina Selatan, transhipment dan yang sandar di pelabuhan karena usaha merugi atau collaps (bangkrut) (Gambar 3). 

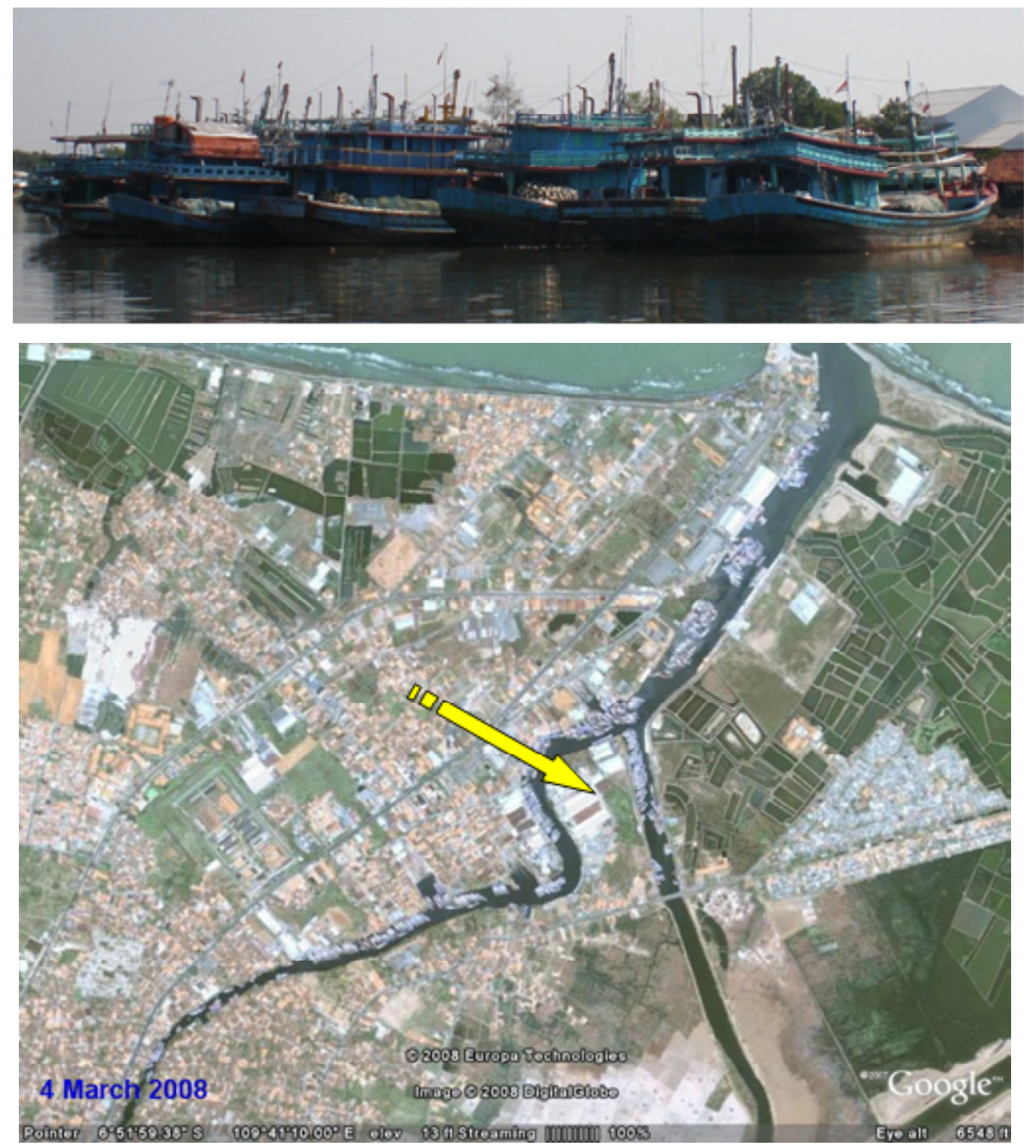

Gambar 3. Beberapa kapal pukat cincin besar yang sandar di pelabuhan Pekalongan karena tidak dapat beroperasi lagi (atas) dan foto citra satelit Pelabuhan Perikanan Nusantara Pekalongan saat ini (bawah).

Keterangan: Arah panah kuning: kapal-pakal yang sandar

Jika jumlah unit kapal pukat cincin asal (register) Pekalongan pada tahun 1995 seluruh sekitar 500-an unit, kapal yang aktif selama tahun 2004 hanya 361 unit, pada 2005 ada 357 unit dan pada tahun 2006 hanya tinggal 288 unit; dengan demikian pada tahun 2006 sekitar 200 unit kapal asal Pekalongan sebagian besar tertambat di pelabuhan tidak beroperasi, sebagian lain memindahkan basis pendaratan ke Juana, bagi pemiliki kapal bermodal kuat melakukan relokasi daerah penangkapan di luar Laut Jawa dan Selat Makassar dengan memindahkan basis pendaratan di Jakarta dan Bitung

Melalui relokasi usaha perikanan mandiri pada akhir tahun 2004, 8 kapal pukat cincin asal Pontianak dan Pekalongan memindahkan fishing base ke Bitung (Sulawesi Utara), diikuti oleh beberapa kapal pukat cincin asal Pekalongan yang beroperasi di Laut Maluku dan Laut Sulawesi (Atmaja, 2006). Berdasarkan pada registrasi oleh Pelabuhan Perikanan Nusantara Pekalongan (Jawa Tengah) menurut SIUP dan IUP terbitan Direktur Jenderal Tangkap pada tahun 2004, dari 330 armada pukat cincin yang terdaftar (jumlah keseluruhan mungkin mencapai 500-an kapal), terdapat 12 unit kapal berbobot 52 sampai dengan 147 GT yang memindahkan izin penangkapan ke Laut Banda, Laut Sulawesi-Pasifik Selatan, Laut Timor, dan ZEE Samudera Hindia, yaitu dengan melakukan substitusi alat tangkap pukat cincin dengan alat long line. Pada 
Tabel 1. Komposisi aktivitas penangkapan (dalam \%) pukat cincin yang mendarat di Pekalongan (Jawa Tengah) menurut daerah penangkapan

\begin{tabular}{|c|c|c|c|c|c|c|c|c|c|c|}
\hline \multirow{2}{*}{ Tahun } & \multicolumn{9}{|c|}{ Daerah penangkapan } & \multirow{2}{*}{$\mathbf{n}$} \\
\hline & 1 & 2 & 3 & 4 & 5 & 6 & 7 & 8 & 9 & \\
\hline 2004 & 0,7 & 3,1 & 13,9 & 1,8 & 29,4 & 32,2 & 5,6 & 11,0 & 2,2 & 1.749 \\
\hline 2005 & 0,1 & 1,6 & 13,0 & 20,1 & 23,7 & 23,9 & 4,7 & 9,5 & 3,4 & 1.441 \\
\hline 2006 & 1,8 & 2,4 & 16,7 & 2,2 & 9,0 & 17,9 & 6,6 & 8,7 & 34 & 981 \\
\hline Keterangan: & $\begin{array}{l}\text { 1. pera } \\
\text { Bawea } \\
\text { 7. per } \\
\text { Juana, }\end{array}$ & ekita & $\begin{array}{l}\text { dan P } \\
\text { itar Ke } \\
\text { ulauan } \\
\text { pment }\end{array}$ & gean; & $\begin{array}{l}\text { erairan } \\
\text { mbu; } 5 \\
\text { erairan } \\
\text { okasi) }\end{array}$ & $\operatorname{tar} \mathrm{Ke}$ & $\begin{array}{l}\text { an K } \\
\text { Dulau } \\
\text { Laut }\end{array}$ & $\begin{array}{l}\text { njawa; } \\
\text { sirih; } \\
\text { Selata }\end{array}$ & rairan & itar Pula \\
\hline
\end{tabular}

awal tahun 2006 beberapa armada pukat cincin bergerak ke perairan Bengkulu (fishing base di Jakarta) dan Laut Arafura. Penurunan jumlah trip juga menunjukkan berkurang jumlah kapal aktif.

\section{Penurunan Jumlah Kapal Aktif dan Jumlah Trip}

Jumlah kapal aktif dan jumlah trip kapal pukat cincin yang mendarat di Pekalongan dan Juana cenderung makin menurun. Penurunan jumlah kapal yang mendarat di Pekalongan terjadi sejak tahun 1998, yaitu dari 434 unit kapal pada tahun 1998 menjadi 358 kapal pada tahun 2005, dan pada tahun 2006 (bulan Januari sampai dengan September) hanya 256 unit kapal pukat cincin, sedangkan jumlah trip yang tercatat masing-masing 3.776, 1.432, dan 619 trip. Dalam setahun, antara tahun 2005 sampai dengan 2006, ada 64 kapal pukat cincin tidak lagi masuk ke Pekalongan (data sampai dengan tanggal 7 Desember 2006) (Tabel 2).

Tabel 2.

Jumlah kapal aktif dan jumlah trip pukat cincin yang mendarat di Pekalongan dan Juana tahun 1986 sampai dengan 2006

\begin{tabular}{ccccc}
\hline \multirow{2}{*}{ Tahun } & \multicolumn{2}{c}{ Jumlah kapal aktif } & \multicolumn{2}{c}{ Jumlah Trip } \\
\cline { 2 - 5 } & Pekalongan & Juana & Pekalongan & Juana \\
\hline 1986 & 377 & - & 3.431 & - \\
1991 & 369 & - & 3.210 & - \\
1994 & 449 & - & 3.188 & - \\
1998 & 434 & - & 3.776 & 1.118 \\
1999 & - & 209 & - & 1.255 \\
2000 & 411 & 243 & 2.302 & 1.325 \\
2001 & - & 292 & - & 1.888 \\
2002 & 401 & 440 & 2.085 & 1.805 \\
2003 & - & 407 & - & 1.414 \\
2004 & 364 & 335 & 1.747 & 1.129 \\
2005 & 358 & 318 & 1.432 & - \\
\hline
\end{tabular}

Keterangan: ${ }^{*}$ = sampai dengan tanggal 7 Desember 2006

Sebaliknya, peningkatan aktivitas pendaratan di Juana, yaitu dari 209 kapal (1.118 trip) pada tahun 1999 menjadi 440 kapal (1.888 trip) pada 2002; namun sejak itu penurunan jumlah kapal aktif dan jumlah trip terus terjadi sampai dengan tahun 2005 (318 kapal 1.129 trip). Meskipun penurunan aktivitas pendaratan di Pekalongan sampai dengan 2002 ini berhubungan dengan kenaikan aktivitas di Juana karena menyangkut operasional dalam pelelangan, namun secara keseluruhan sejak tahun 2002 penurunan aktivitas (jumlah kapal aktif dan jumlah trip) berlangsung di ke-2 tempat pendaratan tersebut. Mudah diduga, penurunan aktivitas ini akibat hasil yang diperoleh tidak menguntungkan lagi secara ekonomi karena tidak lagi seimbang dengan biaya eksploitasi yang semakin besar.
Penurunan jumlah trip dari tahun ke tahun juga terlihat dari penurunan rata-rata trip per kapal pukat cincin seperti diperlihatkan pada Tabel 3, dari 8,7 trip per kapal pada tahun 1991 menjadi 5,2 trip per kapal pada tahun 2002, 4,0 trip per kapal pada tahun 2005, dan hanya 3,3 trip per kapal pada tahun 2006; sedangkan di Juana dari tahun 1999 sampai dengan 2005 berturut-turut terus menurun dari 5,3 trip per kapal pada tahun 1999 menjadi 5,1; 4,5; 4,3; 4,3; 4,2; dan 3,5 trip per kapal pada tahun 2005.

Penurunan rata-rata trip per kapal telah jelas mengindikasikan jumlah hari operasi di laut yang semakin lama dalam setiap trip, namun hari operasi yang lebih lama ternyata tidak memberikan hasil tangkapan yang semakin besar. Peningkatan rata- 
rata hari operasi seperti tertera pada Tabel 4 menunjukkan bahwa nelayan semakin sulit menemukan gerombolan ikan akibat makin susut biomassa ikan pelagis dan posisi tidak menentu di suatu daerah penangkapan sehingga nelayan berpindah-pindah lokasi untuk memperoleh hasil tangkapan yang memadai. Untuk hal tersebut, perlu waktu lebih lama. Peningkatan rata-rata jumlah hari operasi di laut nampak jelas terlihat di hampir seluruh daerah penangkapan utama, baik di Laut Jawa, Selat Makassar, sekitar Kangean, dan Laut Cina Selatan (Tabel 5).

Tabel 3. Rata-rata trip per kapal pukat cincin yang mendarat di Pekalongan dan Juana (Jawa Tengah)

\begin{tabular}{ccccc}
\hline \multirow{2}{*}{ Tahun } & \multicolumn{2}{c}{ Pekalongan } & \multicolumn{2}{c}{ Juana } \\
\cline { 2 - 5 } & Rata-rata trip per kapal & N (kapal) & Rata-rata trip per kapal & N (kapal) \\
\hline 1986 & 9,1 & 377 & - & - \\
1991 & 8,7 & 449 & - & - \\
1994 & 7,1 & 434 & - & - \\
1998 & 8,7 & - & - & 208 \\
1999 & - & 411 & 5,3 & 243 \\
2000 & 5,6 & - & 5,1 & 291 \\
2001 & - & 401 & 4,5 & 440 \\
2002 & 5,2 & - & 4,3 & 407 \\
2003 & - & 364 & 4,3 & 335 \\
2004 & 4,8 & 358 & 4,2 & 318 \\
2005 & 4,0 & 294 & 3,5 & $164^{*}$ \\
2006 & 3,3 & & - & \\
\hline
\end{tabular}

Keterangan: * = sampai dengan Juli 2006

Sumber: Pelabuhan Perikanan Nusantara Pekalongan (Jawa Tengah) dan tempat pendaratan ikan Bajomulyo (Juana)

Tabel 4. Perubahan rata-rata hari laut kapal pukat cincin yang mendarat di Pekalongan menurut daerah penangkapan (keterangan daerah penangkapan pada Tabel 1)

\begin{tabular}{|c|c|c|c|c|c|c|c|c|c|c|}
\hline \multirow{2}{*}{ Tahun } & \multicolumn{9}{|c|}{ Daerah penangkapan } & \multirow{2}{*}{ Total } \\
\hline & 1 & 2 & 3 & 4 & 5 & 6 & 7 & 8 & 9 & \\
\hline 2002 & 11 & 26 & 34 & 43 & 32 & 41 & 29 & 55 & 34 & 35 \\
\hline 2003 & 17 & 23 & 37 & 32 & 37 & 36 & 32 & 53 & 37 & 37 \\
\hline 2004 & 33 & 26 & 32 & 39 & 39 & 43 & 37 & 47 & 30 & 40 \\
\hline 2005 & 43 & 36 & 40 & 50 & 48 & 48 & 49 & 56 & 31 & 48 \\
\hline 2006 & 18 & 27 & 53 & 57 & 67 & 68 & 52 & 69 & 83 & 61 \\
\hline $2002-2006$ & 25 & 27 & 39 & 49 & 42 & 46 & 40 & 53 & 43 & 44 \\
\hline
\end{tabular}

Dampak Kenaikan Harga Bahan Bakar Minyak Pada Bulan Oktober 2005

Selain biomassa yang telah menurun, kenaikan harga bahan bakar minyak pada bulan Oktober 2005 telah makin memukul perikanan pukat cincin. Artinya biaya eksploitasi yang sebelumnya telah tinggi menjadi semakin tinggi, sedangkan hasil yang diperoleh tidak dapat menutup biaya eksploitasi. Jumlah kapal yang mendarat di Juana pada bulan Oktober 2005 ada 127 unit, pada bulan Nopember 2005 turun drastis menjadi hanya 9 unit, dan pada bulan Desember 2005 sampai dengan Maret 2006 berturut-turut 49, 79, 46, dan 11 unit. Demikian juga di Pekalongan, jumlah kapal yang mendarat pada bulan Oktober 2005 ada 194 unit, namun pada bulan Nopember 2005 hanya 30 unit, dan pada bulan Desember 2005 sampai dengan Maret 2006 berturutturut $72,67,81$, dan 58 unit. Pada bulan-bulan yang sama (bulan Nopember sampai dengan Maret) tahun sebelumnya (tahun 2004 sampai dengan 2005), jumlah kapal yang mendarat di Juana berturut-turut 91, 133, 103, 104, dan 71 unit; sedang di Pekalongan 150, 165, 130, 165, dan 125 unit. Penurunan jumlah aktivitas (dalam jumlah trip) setelah bulan Oktober 2005 ditunjukkan pada Gambar 4. 


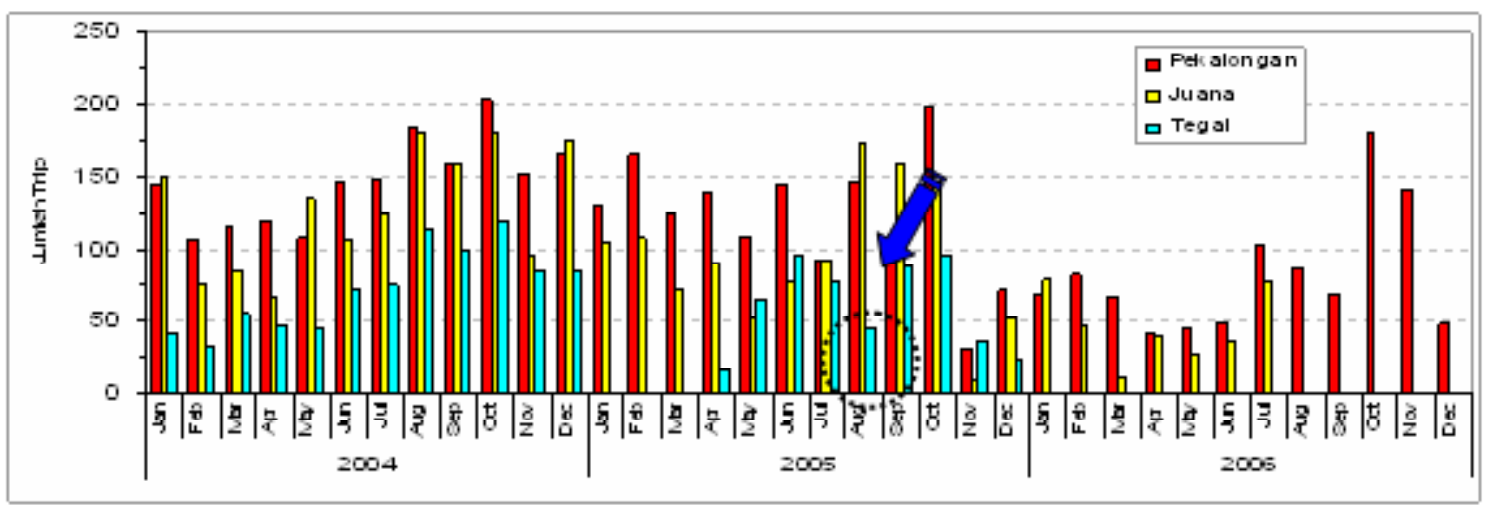

Gambar 4. Fluktuasi jumlah trip kapal pukat cincin yang mendarat di Pekalongan, Juana, dan Tegal, menunjukkan penurunan jumlah trip setelah kenaikan bahan bakar minyak pada bulan Oktober 2005.

\section{Penurunan Laju Tangkap dan Perubahan Komposisi Spesies}

Penurunan yang tajam dari hasil tangkapan juga ditegaskan oleh nilai laju tangkap (dalam ton per trip; dan kg per hari). Pada tahun 2002 hasil tangkapan dapat mencapai 29 ton per trip untuk kapal Pekalongan dan 21 ton per trip untuk kapal Juana, tetapi selanjutnya hanya 25 ton per trip pada tahun 2006 untuk kapal Pekalongan dan 21 ton per trip pada 2003 untuk kapal Juana. Hasil tangkapan per hari terus menurun dari rata-rata $1.000 \mathrm{~kg}$ per hari pada tahun 2003 menjadi separuh (585 kg per hari) pada tahun 2006. Penurunan laju tangkap ini sangat jelas terjadi di daerah penangkapan utama di Laut Jawa (Karimunjawa, Masalembo, dan Matasirih), Selat Makassar (Lumu-lumu dan Lari-Larian) dan Laut Cina Selatan (Natuna, Midai, dan Pejantan) (Tabel 5). Penurunan laju tangkap nampak kurang signifikan di daerah penangkapan sekitar Kepulauan Kangean.
Gambar 5 memperlihatkan fluktuasi musiman laju tangkap di setiap daerah penangkapan utama.

Secara tahunan, perubahan komposisi spesies ikan pelagis yang tertangkap perikanan pukat cincin mungkin kurang nyata. Ikan layang (Decapterus sp.) sebagai komponen utama dalam komunitas ikan pelagis kontribusi 56\% pada tahun 1994 (puncak hasil tangkapan); antara tahun 2002 sampai dengan 2006, periode di mana catch tahunan telah menurun (sejak tahun 1999) kontribusi berkisar antara 42 sampai dengan 57\% (Tabel 6 dan Gambar 6). Penurunan hasil tangkapan layang terlihat pada tahun $2003(45 \%)$ dan tahun 2005 (42\%), diimbangi oleh kecenderungan kenaikan persentase ikan bentong (Selar crumenopthalmus) dari sebelumnya hanya $6 \%$ pada tahun 1994 menjadi 8 sampai dengan 12\% antara tahun 2002 sampai dengan 2006. Kecenderungan penurunan juga terjadi pada ikan jui dan ikan banyar (Rastrelliger kanagurta), di mana pada tahun 1994 masing-masing memberi kontribusi 13 dan $8 \%$, namun pada tahun 2006 hanya 6 dan 3\%.

Tabel 5. Penurunan laju tangkap (kg per hari) pukat cincin yang mendarat di Pekalongan menurut daerah penangkapan (keterangan daerah penangkapan pada Tabel 1)

\begin{tabular}{|c|c|c|c|c|c|c|c|c|c|c|}
\hline \multirow{2}{*}{ Tahun } & \multicolumn{9}{|c|}{ Daerah penangkapan } & \multirow{2}{*}{ Rata-rata } \\
\hline & 1 & 2 & 3 & 4 & 5 & 6 & 7 & 8 & Unknown & \\
\hline 2002 & 505 & 772 & 714 & 878 & 1.027 & 835 & 2.010 & 858 & - & 930 \\
\hline 2003 & 1.449 & 638 & 415 & 974 & 921 & 1.267 & 1.248 & 756 & - & 1.001 \\
\hline 2004 & 632 & 794 & 1.072 & 843 & 1.036 & 960 & 1.169 & 858 & 767 & 989 \\
\hline 2005 & 95 & 566 & 553 & 536 & 661 & 730 & 688 & 756 & 353 & 646 \\
\hline 2006 & 711 & 530 & 694 & 510 & 368 & 330 & 1.192 & 592 & 1.205 & 585 \\
\hline Rata-rata & 685 & 682 & 794 & 579 & 878 & 865 & 1.088 & 779 & 1.090 & 835 \\
\hline
\end{tabular}




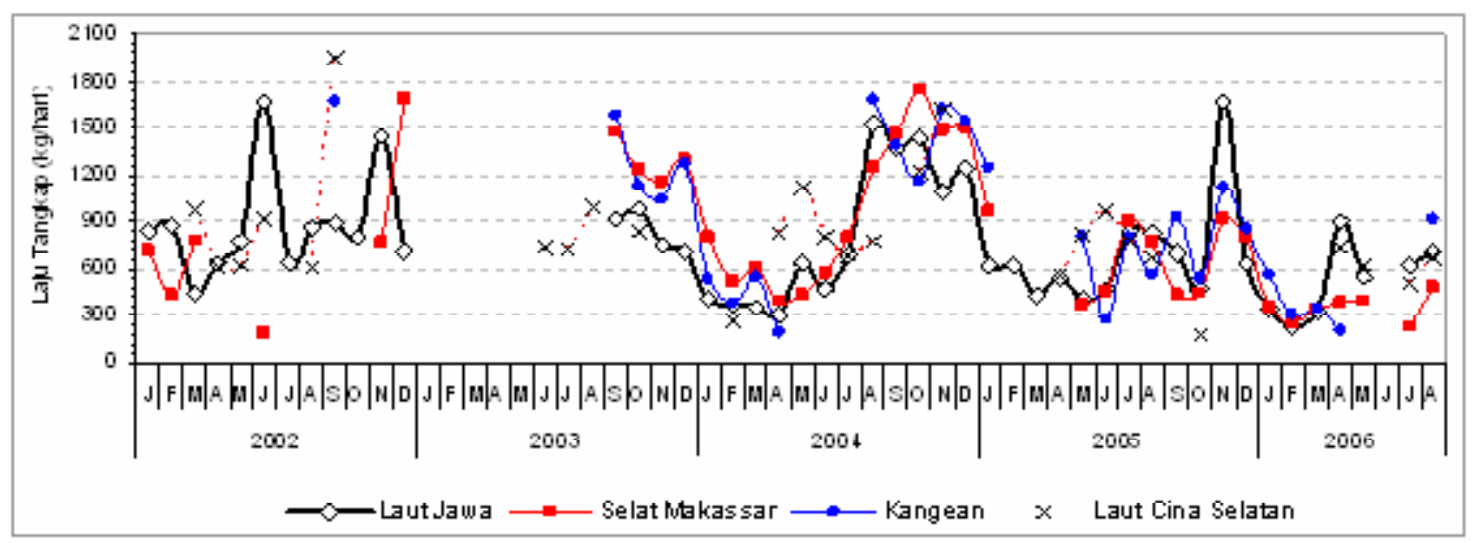

Gambar 5. Fluktuasi musiman laju tangkap (kg per hari) pukat cincin di perairan Laut Jawa, Selat Makassar, Kepulauan Kangean, dan Laut Cina Selatan.

Tabel 6 .

Komposisi (\%) ikan pelagis kecil yang tertangkap pukat cincin Pekalongan

\begin{tabular}{|c|c|c|c|c|c|c|}
\hline Jenis & 1994 & 2002 & 2003 & 2004 & 2005 & 2006 \\
\hline $\begin{array}{l}\text { Ikan layang (Decapterus sp.) } \\
\text { Ikan banyar (Rastreliger kanagurta) }\end{array}$ & $\begin{array}{l}56 \\
13\end{array}$ & $\begin{array}{c}51 \\
7\end{array}$ & $\begin{array}{c}45 \\
7\end{array}$ & $\begin{array}{c}57 \\
7\end{array}$ & $\begin{array}{c}42 \\
8\end{array}$ & $\begin{array}{l}55 \\
6\end{array}$ \\
\hline Ikan bentong (Selar crumenopthaimus) & 6 & 11 & 10 & 8 & 11 & 12 \\
\hline Ikan siro (Ambiygaster sim) & 12 & 8 & 14 & 11 & 10 & 11 \\
\hline Ikan tembang (Sardinella fimbriata) & 8 & 6 & 5 & 4 & 3 & 3 \\
\hline Ikan tongkoliTengiri (Euthymnus afinis) & 2 & 5 & 7 & 6 & 6 & 3 \\
\hline Ikan teros (Mene maculata) & 0 & 0 & 0 & 1 & 3 & 2 \\
\hline Ikan ayam-ayaman (Aiutens monoceros) & 0 & 3 & 5 & 1 & 10 & 0 \\
\hline Lain-lain & 3 & 9 & 7 & 5 & 7 & 8 \\
\hline Jotal catch (ton) & 98.900 & 47.300 & 50.500 & 54.100 & 38.800 & 22.000 \\
\hline
\end{tabular}

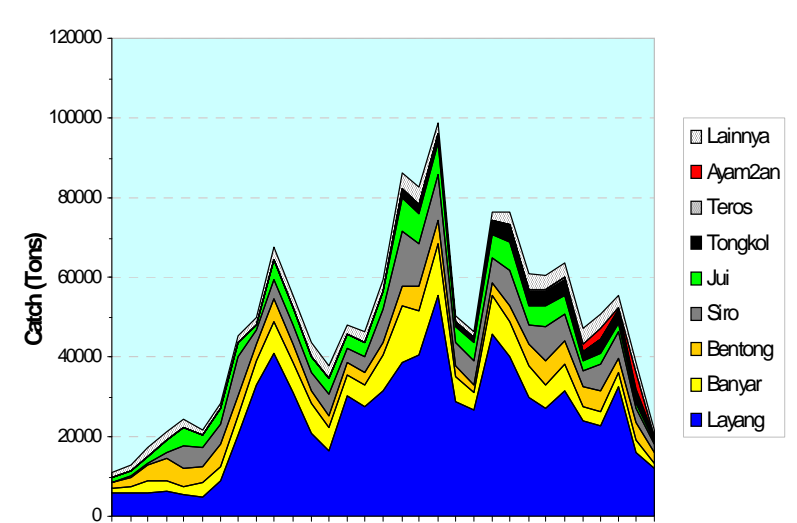

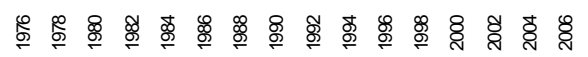

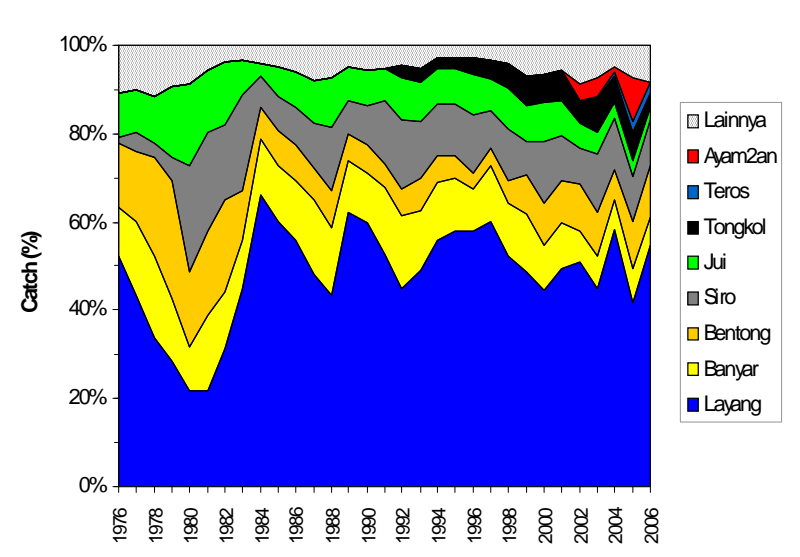

Gambar 6. Variasi tahunan komposisi spesies ikan pelagis kecil yang tertangkap pukat cincin Pekalongan.

Selain perubahan komposisi spesies (\%) seperti tersebut di atas, sejak tahun 2002 muncul spesies lain berupa ikan ayam-ayaman atau leather jackets (Aluterus monoceros, famili Monacanthidae) (nama lain: ikan gendut, semar, dan pungkur) (Gambar 6) dan ikan teros (Mene maculata). Hasil tangkapan ikan ayam-ayaman oleh pukat cincin Pekalongan 4.576 $\mathrm{kg}$ pada tahun $2002,2.032 .530 \mathrm{~kg}$ pada tahun 2003 , $190.992 \mathrm{~kg}$ pada tahun 2004, 3.897.347 pada tahun
2005, namun sangat menurun pada tahun 2006 yaitu hanya $9.695 \mathrm{~kg}$. Pada kurun waktu tahun 2002 sampai dengan 2003 dan tahun 2005 spesies baru tersebut memberi kontribusi cukup besar dalam hasil tangkapan; meski secara tahunan kontribusi paling besar hanya $10 \%$ dari total tangkapan, namun pada musim ikan (bulan September sampai dengan Nopember) kontribusi dapat mencapai $13,4 \%$ pada 
Kontribusi spesies ini terutama muncul pada musim peralihan 2 yang merupakan musim ikan di perairan ini (Gambar 8); selain itu, pada musim barat juga tertangkap di Selat Makassar. Selain itu, di sekitar Matasirih juga merupakan habitat utama spesies ini, hasil tangkapan kira-kira 50\% dari seluruh hasil tangkapan jenis ini yang tertangkap di Karimunjawa, Bawean, Masalembo, Matasirih, Makassar, Kangean, dan Natuna (Gambar 9).

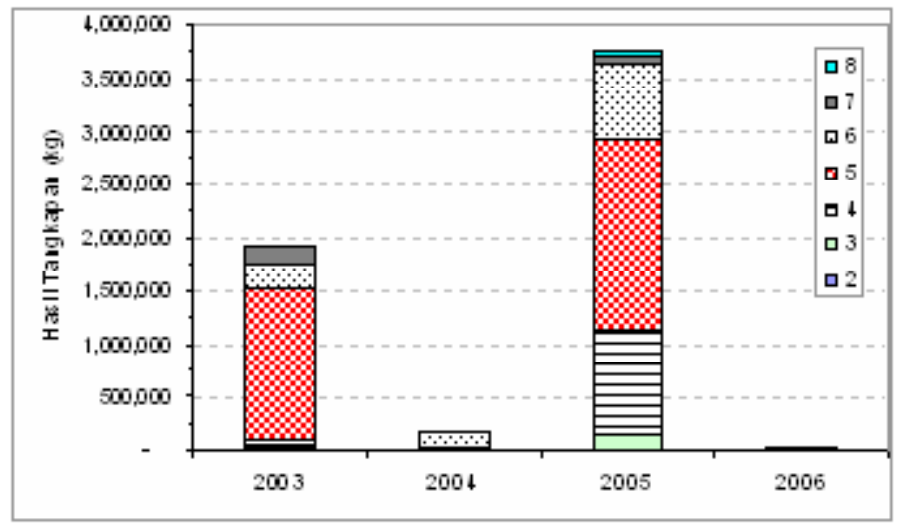

Gambar 7. Hasil tangkapan ikan ayam-ayaman atau Leather-jackets (Aluterus monoceros, famili Monacanthidae) yang tertangkap di sekitar Laut Jawa dan didaratkan di Pekalongan.

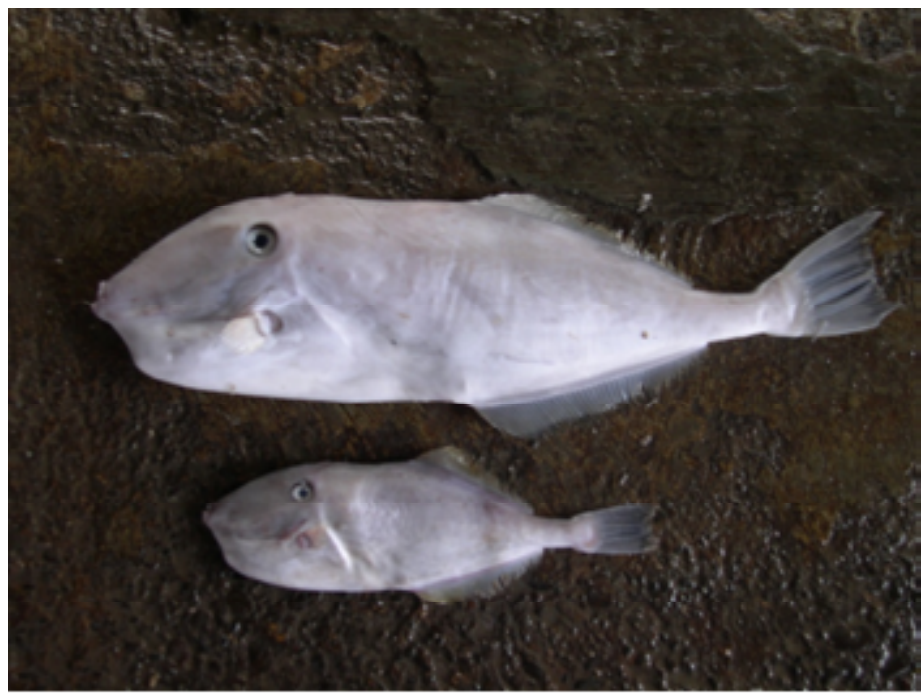

Gambar 8. Ikan ayam-ayaman atau gendut atau semar atau pungkur, Leatherjackets (Aluterus monoceros, famili Monacanthidae); memperlihatkan 2 kategori ukuran: a. ikan dewasa (ukuran 48 sampai dengan $55 \mathrm{~cm}$ ) dan b. ikan muda (ukuran 21 sampai dengan $35 \mathrm{~cm}$ ).
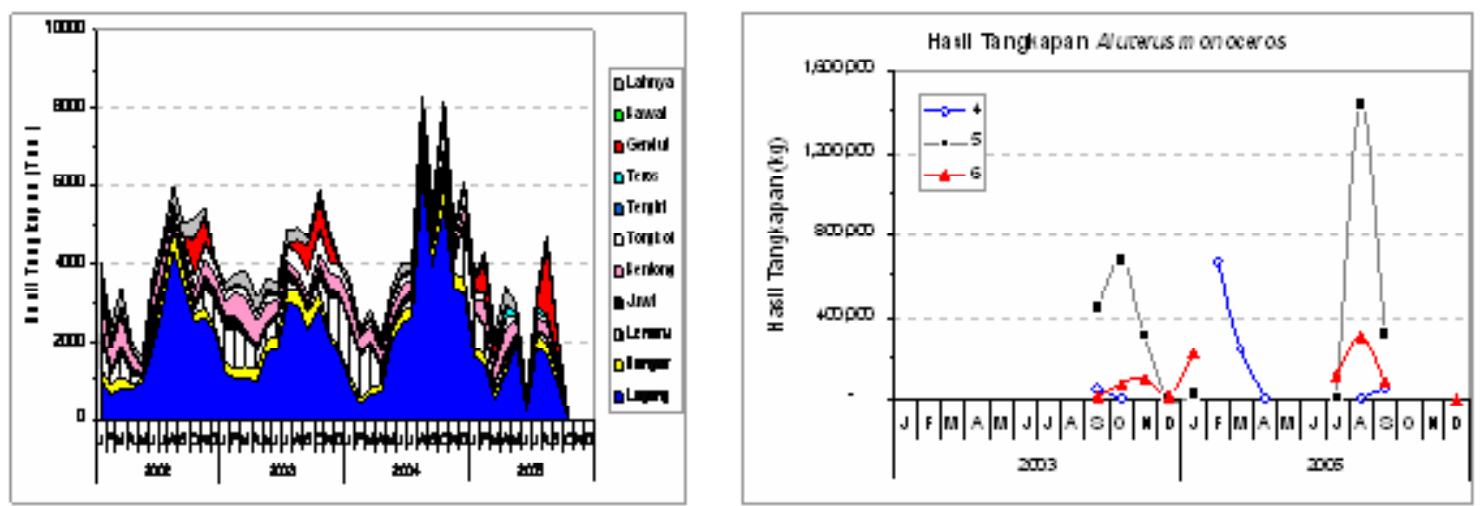

Gambar 9. Fluktuasi hasil tangkapan ikan pelagis yang didaratkan di Pekalongan. 


\section{KESIMPULAN DAN SARAN}

Dari uraian tersebut di atas dapat disimpulkan sebagai berikut:

1. Pada periode terakhir (tahun 2003 sampai dengan 2006) beberapa perubahan dalam upaya terjadi pada perikanan pukat cincin sebagai respon rendah hasil tangkapan di sekitar Laut Jawa akibat penyusutan biomassa. Sedikit pergeseran aktivitas tertuju pada hasil yang menguntungkan, yaitu terhadap kemunculan spesies baru ikan ayamayaman (Aluterus monoceros, famili Monacanthidae).

2. Jumlah kapal aktif dan jumlah trip semakin menurun karena sejumlah kapal tidak lagi dapat beroperasi (bangkrut, collaps), sedang kapal yang beroperasi nampak tidak efisien yang terlihat dari jumlah hari laut yang semakin lama. Sebagian kapal lain melakukan ekspansi (relokasi) daerah penangkapan baru di luar Laut Jawa-Selat Makassar. Perubahan lain ada usaha transhipment yang diduga dilakukan untuk menghemat bahan bakar minyak.

3. Laju tangkap (ton per trip maupun ton per hari), terus menurun hampir di seluruh daerah penangkapan, disertai kecenderungan perubahan komposisi spesies terutama di daerah penangkapan utama (Jawa bagian timur dan Selat Makassar).

4. Perubahan-perubahan tersebut di atas (relokasi daerah penangkapan, transhipment, dan kenaikan jumlah hari di laut) sebaiknya dimonitor untuk tujuan pengelolaan yang bertanggungjawab. Penanganan terhadap gejala transhipmentjuga hal yang penting karena sedikit banyak telah merusak sistem pendataan hasil tangkapan.

\section{PERSANTUNAN}

Kegiatan dari hasil riset perubahan upaya, hasil tangkapan, dan biologi populasi ikan pelagis kecil di
Laut Cina Selatan, Laut Jawa, dan Selat Makassar, T.A. 2005-2006, di Balai Riset Perikanan Laut-Muara Baru, Jakarta.

\section{DAFTAR PUSTAKA}

Atmaja, S. B. 2006. Perkembangan perikanan pukat cincin dan kondisi biomassa ikan pelagis di Laut Jawa dan sekitarnya. Dipresentasikan pada Sosialisasi Hasil Kegiatan Riset. Pusat Riset Perikanan Tangkap. Balai Besar Pengembangan Penangkapan Ikan Semarang. 14 Desember 2006.

Atmaja, S. B. \& B. Sadhotomo. 1985. Aspek operasional pukat cincin di Laut Jawa. Laporan Penelitian Perikanan Laut. Jakarta. 32. 65-71.

Djadjuri, H. 1978. Perikanan purse seine di Batang dan pembuatan kapal-kapal purse seine. Simposium Modernisasi Perikanan Rakyat. Lembaga Penelitian Perikanan Laut. $12 \mathrm{p}$.

Durand, J. R. \& J. Widodo. 1997. Final report Java Sea pelagic fishery assessment project. ALA/INS/ 87/17. AARD-ORSTOM/EEC. Sci. Tech. Doc. No.26. $76 \mathrm{p}$.

Martosubroto, P. 2005. Menuju pengelolaan perikanan yang bertanggungjawab. Forum Pengkajian Stok Ikan Laut. Hotel Bintang. Jakarta. 27-28 Desember 2005.

Nurhakim, S., B. Sadhotomo, \& M. Potier. 1995. Composite model on small pelagic resources in the Java Sea. In Biology, Dynamics, Exploitation of the Small Pelagic Fishes in the Java Sea. AARD/ORSTOM. 145-153.

Potier, M. 1998. Pêcherie de layang et senneurs semi industriels Javanais: Perspective historique et approche système. Phd Thesis. Université de Montpellier II. $280 \mathrm{p}$. 